\title{
PBL-Based Interactive Multimedia in Improving Critical Thinking Skills
}

\begin{abstract}
Abdulah $^{1^{*}}$, Ali Mustad ${ }^{2}$, Windi Fitriani ${ }^{3}$
1,2,3 Primary Education, Postgraduate Program, State University of Yogyakarta, Yogyakarta, Indonesia e-mail: abdulah.2019@student.uny.ac.id ${ }^{1}$, ali mustadi@uny.ac.id², windifitriani.2019@student.uny.ac.id ${ }^{3}$

Abstract

This study aims to develop interactive multimedia based on problem-based learning and to find out its effectiveness against increasing critical thinking skills. This research uses a Research and Development approach. The research data was obtained through the media validation sheet instrument by experts and the critical thinking skills test instrument. Data analysis in this study used the independent $t$-test. Based on the results of the media validation test by the expert shows that the interactive multimedia that has been developed has the criteria of "Good". Then the product effectiveness test results using the independent $t$-test showed that interactive multimedia based on problem-based learning proved to be able to improve critical thinking skills in students. The results of this discovery have implications in learning, namely to improve critical thinking skills in students, it can be done by using interactive multimedia based on problem-based learning.
\end{abstract}

Keywords: Interactive Multimedia, PBL, Critical Thinking

\section{Introduction}

The rapid development of science and technology has an impact on the educational process. Education is required to be able to develop and improve students to be able to have various life skills, especially life skills in the 21st century. Therefore, students will be ready to face the development of science and technology. One of the skills that can help students to deal with these developments is critical thinking. Critical thinking is a basic skill that students should master in the 21st century (Trilling \& Fadel, 2009). Critical thinking is very important for the curriculum in the future (Griffin, 2012). The reason is because critical thinking skills help students to be able to think and function as responsible citizens in a world (Vieira \& TenreiroVieira, 2014) and enable students to solve problems in the modern world (Ulger, 2018). Critical thinking is the ability to solve a problem, analyze information and make decision (Nargundkar, 2014). Critical thinking skills help students to be able to evaluate various issues from a social and environmental perspective, develop their analytical skills and make informed choices in daily life (Mapeala \& Siew, 2015). In conclusion, critical thinking is not just a high-level activity to gain knowledge (Castle, 2006). It includes other intellectual thinking skills such as reasoning, analysis, problem solving, reading comprehension, scientific thinking, creative thinking, accurate assessment and decision making (Sarigoz, 2012). Through this skill, students can analyze, evaluate, and make decisions about a problem appropriately. Therefore, critical thinking skills should be improved in learning activities in the classroom.

Based on the results of the preliminary observations on grade $V$ elementary school students in Depok, Sleman Regency, critical thinking skills of students are still low. This can be seen in the learning activities. Students have difficulties to analyze and find learning materials. The low critical thinking in students is caused by the lack of available learning media that can improve critical thinking skills. As in science learning activities, science learning has an important role in fostering critical thinking skills, so that students' critical thinking skills in science learning need to be improved. However, in reality the students' critical thinking skills in science learning are still low (Budiana, et al., 2013). So that in science learning activities, teachers should apply innovative learning strategy and instructional media so that learning materials can be absorbed well by the students (Widiana, 2016).

\footnotetext{
${ }^{*}$ Corresponding author.

Received 16 June 2020; Accepted 23 September 2020; Available online 25 March 2021

(C) 2020 JPI. All Rights Reserved
}

Jurnal Pendidikan Indonesia (JPI) | 136 
One of the efforts that can be made to improve critical thinking skills is through learning innovation using interactive multimedia. The use of multimedia has an important role in the learning process in elementary schools where the optimization of multimedia is able to make learning activities be more effective (Diputra, 2016).

Giavrimis et al. stated that the implementation of interactive multimedia with appropriate learning methods can improve critical thinking skills on students (Giavrimis et al., 2011). The combination of interactive multimedia with a problembased learning approach can develop students' thinking skills (Gunawan, 2019). This shows that interactive multimedia can not only be combined with learning methods, but can also be combined with the right learning approach, namely the problem-based learning approach. Problem based learning is a learning approach that can be used to improve critical thinking skills (Goertel, 2018). PBL is a learning approach that has the potential to meet the skills development needs of various student study groups (Joham \& Clarke, 2012). Problem based learning is a learning approach that can improve student academic achievement (Merritt, Lee, Rillero, \& Kinach, 2017). It includes several stages such as understanding, application, analysis, synthesis, and evaluation. Problem based learning provides an opportunity for students to consider the facts obtained related to the specific problems faced (Golightly \& Raath, 2015). Problem based learning is a curriculum model designed based on problems in real life in the surrounding environment (Glenview, 1997).

Research conducted by Ozturk et al., showed that problem based learning can encourage students' ability to think critically, to be tolerant of other people's ideas, and evaluate conflicting information before concluding a problem (Ozturk et al.,, 2008). In addition, research conducted by Liu et al., showed that the use of multimedia with the problembased learning approach significantly increased students' knowledge and scientific attitudes (Liu et al., 2018). Problem based learning can be applied to improve student skills in the learning process and can also be applied to increase student learning motivation (Shinde \& Inamdar, 2013). Problem based learning has a strong influence on the learning process and student achievement (Moallem et al., 2019).

Based on the explanation above, research and development of interactive multimedia based on problem-based learning needs to be done in order for students to receive the subject matter well. As it is stated by Diputra, the use of multimedia in learning makes it easier for students to understand the subject matter through the presentation of various images and videos about natural phenomena that are not easily observed by the human senses (Diputra, 2016). On the other hand, the implementation of problem-based learning can train students to think critically, be right the students active and creative for students to experience for themselves what is learned (Darsana, Son, \& Country, 2013).

This study aims to develop a product in the form of interactive multimedia and to determine the effectiveness of interactive multimedia that has been developed on critical thinking skills. The results of this study are expected to contribute solutions to the various problems that occur above and improve students' critical thinking skills in elementary schools.

\section{Method}

This study applied Research and Development (R\&D) approach. This research was conducted at 3 elementary schools in Depok, Sleman Regency and was carried out in the odd semester of the 2019/2020 school year. This study used six stages of research adapted from the Borg \& Gall development model. The six stages included preliminary studies, planning, develop initial product, product validation test and initial trials on a limited scale, product revision, and product testing in the main field ( Borg \& Gall, 1983). The design used for product trials in the main field was carried out using the Quasi Experiment method of the Nonequivalent Control Group Design technique. In this design, there is an experimental class with learning treatment using interactive multimedia based on problem-based learning and a control class with learning without using interactive multimedia. 
Table 1. Design nonequivalent control group.

\begin{tabular}{cccc}
\hline Class & Pretest & Treatment & Postest \\
\hline Eksperiment & $\mathrm{O}_{1}$ & $\mathrm{X}$ & $\mathrm{O}_{2}$ \\
Kontrol & $\mathrm{O}_{3}$ & & $\mathrm{O}_{4}$ \\
\hline
\end{tabular}

To get critical thinking skills data, this study used a critical thinking skills test instrument. Indicators of critical thinking skills used in this study are indicators of critical thinking skills from the Test of Science Critical Thinking (TSCT) for Fifth Graders developed by (Mapeala \& Siew, 2015). Some of these indicators include comparing and contrasting skills, sorting, and identifying cause and effect. The research data that has been obtained in this study are then analyzed. Analysis of the data in this study included analysis of data from the test try the product on a limited scale, data analysis results of the validation test media by experts and analysis of test results. The effectiveness of the product is gained by using test $t$ independent.

\section{Result and Discussion Results}

The product in the form of interactive multimedia based on problem based learning has been developed. The steps used by researchers to develop this interactive multimedia use adaptation of development research procedures by Borg \& Gall. The following is the result of developing interactive multimedia products based on problem based learning.

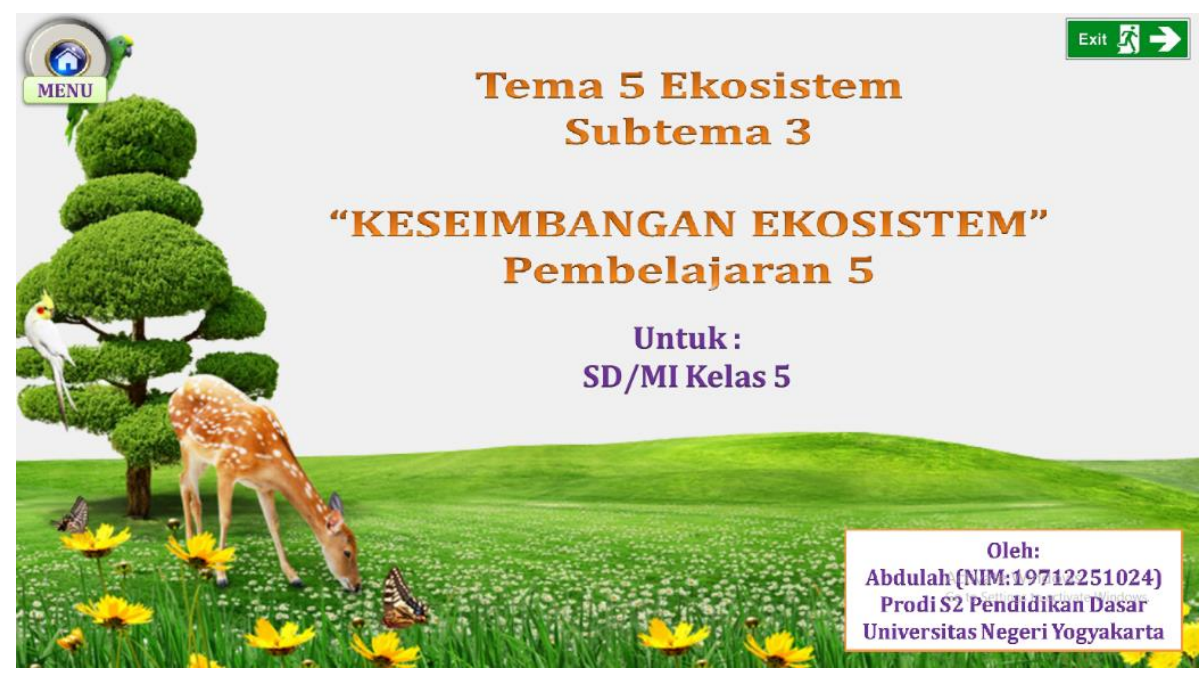

Figure 1. Main page of interactive Multimedia based on PBL

Interactive multimedia based on problem based learning developed in this study has six main menus such as guides on how to use interactive multimedia, learning goals, and learning materials about the balance of the ecosystem. The material in this multimedia equipped with video-related issues in daily life. The videos presented in interactive multimedia are videos related to natural phenomena that are not easily observed by the human senses. Some of the videos include videos of the process of the earthquake, the process of landslides, summary of the material and quiz. 


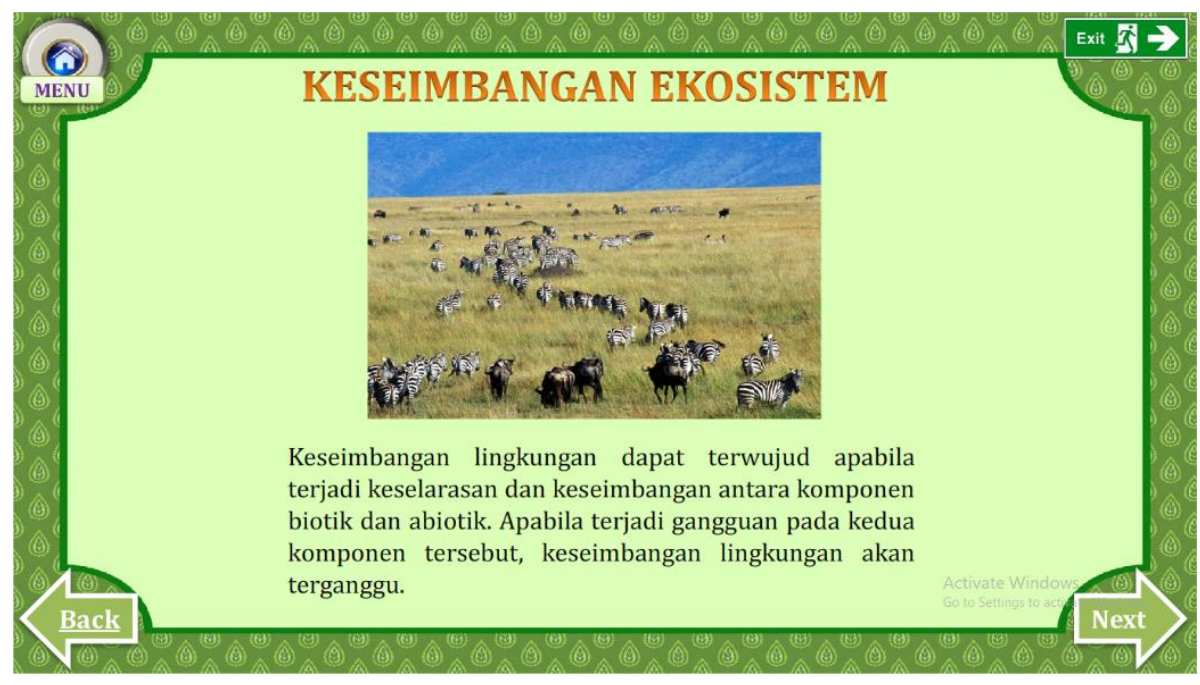

Figure 2. Display of material in interactive Multimedia based on PBL

Interactive multimedia based on problem based learning in this study used the Macromedia Flash 8 application. The material in interactive multimedia is prepared based on problem-based learning designs and it is adjusted to the competencies to be achieved in learning. It is related to ecosystem balance material in elementary school science subject matter. This material is material that includes the factors that cause the balance of the ecosystem and the efforts that can be made so that the balance of the ecosystem is maintained.

After the interactive multimedia based on problem based learning has been developed, the next stage is the interactive multimedia validation test. The following is the result of interactive multimedia validation.

Table 2. Interactive multimedia validation test results

\begin{tabular}{|c|c|c|}
\hline No. & Rated aspect & Score \\
\hline 1. & Suitability of subject matter with multimedia & 4 \\
\hline 2. & Programming quality & 4 \\
\hline 3. & Text legibility & 4 \\
\hline 4. & Color compability & 4 \\
\hline \multirow[t]{5}{*}{5.} & Image quality & 3 \\
\hline & Total Score & 19 \\
\hline & Average & 3,8 \\
\hline & Category & good \\
\hline & Percentage Eligibility & $76 \%$ \\
\hline
\end{tabular}

Based on the results of the interactive multimedia validation test above, it can be seen that the multimedia that has been developed has a score of 19 out of a maximum score of 25 . The average multimedia validation test results obtained a value of 3.8 from a value scale of 5 . After being converted into a percentage, it can be obtained a multiplication value of $76 \%$. Thus, it can be concluded that the interactive multimedia that has been developed has a "Good" category.

After the product validation test has been carried out, the next step is to test the product on a limited scale. Product trials on a limited scale in this study were conducted by asking students to provide responses to interactive multimedia products that have been developed. Data from product trials on a limited scale are used to improve the product. The following are the results of product trials on a limited scale. Based on the results of product trials on a limited scale, it can be seen that the multimedia that has been developed has an 
average student response score of 50.5 from a maximum score of 64 . After being converted into a percentage, it can be obtained a value of $78.91 \%$. Thus, it can be concluded that the results of product trials on a limited scale are in the "Good" category.

After the multimedia is tested on a limited scale, the next step is to revise the product based on the results of the trial analysis on a limited scale. The revised product is then tested in the main field. Product trials in the field were carried out in order to determine the effectiveness of the product on improving critical thinking skills in students. This trial was conducted using a quasi-experimental research design with the nonequivalent control group design technique. Based on the results of the main field test, the experimental class pretest average value was 54.2 and the control class average value was 57.9. Then the post-test results obtained by the experimental class average value of 79.15 and the control class average value of 67.2 .

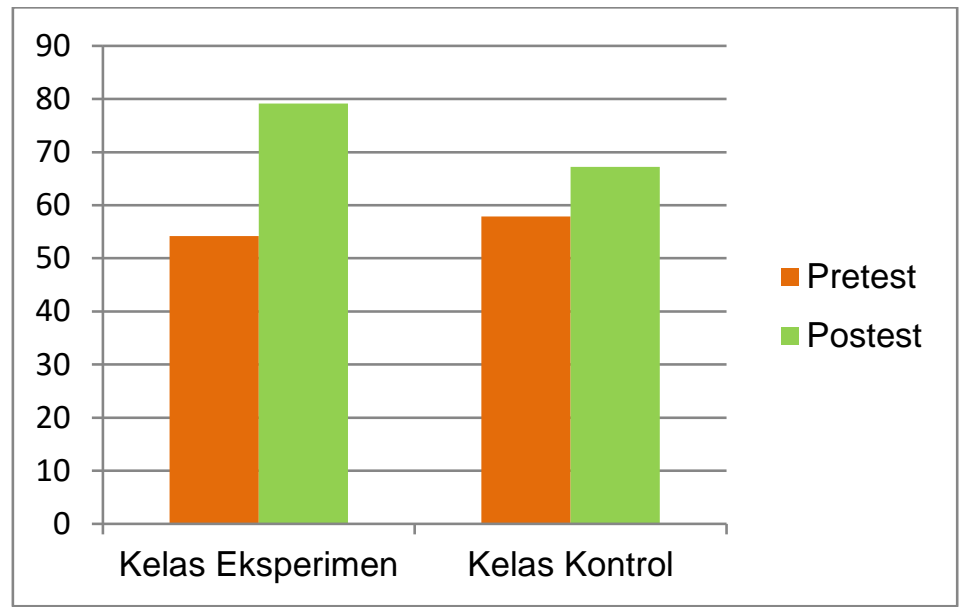

Figure 3. Diagram of the results of the pre-test and post-test critical thinking skills

Based on the diagram above, it can be seen that the post-test results of critical thinking skills in experimental class students who use problem-based learning -based interactive multimedia have increased higher than the control class.

To determine the effectiveness of interactive multimedia based on problem-based learning that has been developed, an independent $t$ test was conducted. The independent $t$ test was conducted in order to determine the significant difference between the post-test scores of the experimental class and the post-test scores of the control class. To perform an independent $t$ test, this study uses the SPSS 23 application. Before conducting the independent $t$ test, first the pretest and post-test data were tested for normality and homogeneity using the SPSS 23 application.

Table 3. Results of the Pre-test and Post-test Normality Test for the Experiment and Control Group

\begin{tabular}{ccccc}
\hline \multirow{2}{*}{ Class } & \multicolumn{2}{c}{ Pretest } & \multicolumn{2}{c}{ Postest } \\
\cline { 2 - 5 } & Sig. & Decision & Sig. & Decision \\
\hline Eksperiment & 0,082 & Normal & 0,110 & Normal \\
Control & 0,445 & Normal & 0,097 & Normal \\
\hline
\end{tabular}

The results of the normality test in table 3 above can be obtained by the pretest significance value of the experimental class of 0.082 and the post-test significance value of 0.110 . Meanwhile, the control class obtained a pretest significance value of 0.445 and a posttest significance value is 0.097 . Based on the normality test that has been carried out on the pre-test and post-test data for the experimental class and control class above, it can be 
concluded that the significance value is more than 0.05 . Therefore, it can have concluded that that the pre-test and post-test data are normally distributed.

Tabel 4. Results of the Pre-test and Post-test of Homogeneity Test for the Experiment and Control Groups

\begin{tabular}{ccc}
\hline Data & Significance & Decision \\
\hline Pretest & 0,552 & Homogeneous \\
Postest & 0,943 & Homogeneous \\
\hline
\end{tabular}

The results of the homogeneity test in table 4 above can be obtained from the pretest significance value of the experimental class and the control class of 0.552 . While the post-test significance value of the experimental class and the control class is 0.943 . Based on the results of the homogeneity test, the pretest and post-test significance values were more than 0.05 . So it can be concluded that the data is homogeneous.

Table 5. Independent t Test Results

\section{t-test for Equality of Means}

\begin{tabular}{llrrr} 
& df & Sig. (2-tailed) & Mean Difference \\
\hline $\begin{array}{l}\text { Postest value of } \\
\text { critical thinking } \\
\text { skills }\end{array}$ & $\begin{array}{l}\text { Equal variances } \\
\text { Essumed }\end{array}$ & 38 &, 000 & 11,95000 \\
& $\begin{array}{l}\text { Equal variances not } \\
\text { assumed }\end{array}$ & 37,911 &, 000 & 11,95000 \\
\hline
\end{tabular}

Based on the $T$ Independent test that has been carried out, a significance value of $0.000<0.05$ can be obtained. So it can be concluded that there is a significant difference between the post-test in the experimental class and the post-test in the control class.

\section{Discussion}

Based on the results of the hypothesis testing that has been done, it can be seen that there is a significant difference in critical thinking skills in the experimental class and the control class. This proves that the use of interactive multimedia based on problem based learning is effectively applied to improve students' critical thinking skills. The results of this study showed that students who participated in the learning using interactive multimedia-based on problem-based learning have the critical thinking skills better than the students who take the learning without the use of interactive multimedia-based problem-based learning.

Integrating interactive multimedia with problem based learning for science learning is efficient. Through the integration of these two things, it will be easier for students to understand and link the concepts in science learning with everyday life. As it is stated by Asta et al., that science learning is not only emphasizes the memorization of concepts, but rather to how to make students able to associate the concepts of those in the surrounding environment (Asta et al., 2015). However, there are several things that must be considered before integrating the Problem Based Learning approach in interactive multimedia, including adjusting the material to be taught. Material being taught in the classroom should be related to problems in everyday life. The problem presented in problem-based learning is a description of a series of phenomena that can be observed in the real world (Moallem et al., 2019).

The findings in this study are supported by the results of research conducted by Ismail, et al., showing that the problem-based learning approach that is integrated into the application development design for learning scientific terms has a positive effect on students' critical thinking skills (Ismail, et al., 2018). Research conducted by Devi \& Bayu showed that the application problem based learning aided visual media had impacted critical thinking skills and science learning outcomes of students in primary schools (Devi \& Bayu, 2020). As it is 
stated by Fung \& Liang that problem based learning has a contribution to critical thinking skills (Fung \& Liang, 2019). Critical thinking skills have a very important role for a person to be able to play a role in social life. Critical thinking skills are one of the skills aspects that are very important to be able to develop in the 21st century. These skills are needed to be able to contribute as a member of society (Carlgren, 2013). Learning critical thinking skills helps students to be able to select and process the information obtained. In addition, it also helps students to find effective ways to achieve a goal and thus become better problem solvers and decision makers (Lin, 2018).

The principle of problem-based learning is inquiry, deepening understanding of a particular learning (Filipenko \& Naslund, 2015). So that by applying learning with this approach will make learning easy to understand and make students more active in the learning process. This is because problem based learning is one of the approaches to student-centered and interactive learning (Bijsmans \& Schakel, 2018) and it is related to real life situations (Filho, 2018).

This research showed that the use of interactive multimedia combined with a problembased learning approach is effectively applied in the learning process specially to improve critical thinking skills. Interactive multimedia can present a variety of problems related to the phenomena of nature that are not easily observed by human senses such as the process of earthquakes, landslides, and several other natural events or phenomena. The presentation of these events in the learning process will support the principle of problem-based learning, because the presented events are events that are easily observed. As it is stated by Moallem et al., that the problem presented in problem-based learning is a description of a series of phenomena that can be observed in the real world (Moallem et al., 2019).

With the presence of real events or phenomena in learning, it will help students to find out the causes of these events. Besides that, it will also help students to find solutions to problems that exist in the real world through critical thinking skills. Learning with a problembased leaning approach provides students the opportunity to learn to solve problems in real life (Westwood, 2008). Thus learning will be more meaningful. As stated by Moallem et al., (2019) that by implementing a problem-based learning approach, learning will be more meaningful. This is because students learn their problems in everyday life (Moallem et al., 2019). Problem based learning encourages students to learn about real-world problems as a context for learning to think critically (Effendi \& Hendriyani, 2019). The initial analysis of a problem in problem-based learning serves to reactivate the knowledge that students already have (Moallem et al., 2019). In addition, problem based learning has several advantages, including encouraging self-direction in the learning process, preparing students to think critically and analytically, empowering students to identify, find and use appropriate resources, the problems studied are closely related to the real world and motivate. students, active involvement in integrating information and skills in expressing ideas or opinions, improve communication skills and social skills necessary for cooperation and teamwork (Westwood, 2008).

Based on the explanation above, this research has the implication that the application of interactive multimedia based on problem based learning has a positive contribution in improving students' critical thinking skills. The results of the analysis and findings in this study indicate that there is a significant difference in critical thinking skills between the experimental class using interactive multimedia based on problem-based learning and the control class. The results of these findings indicate that the development of interactive multimedia based on problem learning is proven effective to be applied in the learning process.

\section{Conclusions and Suggestions}

Based on the results of the discussion above, it can be concluded that interactive multimedia based on problem-based learning that has been developed has good criteria based on the results of the multimedia validation test. Then based on the analysis of product trials on a limited scale, the developed interactive multimedia has a good category. The post-test average score of critical thinking skills in the experimental class is higher than the control class. In addition, based on the interactive multimedia effectiveness test based on problem- 
based learning using the independent $t$ test, it was proven that there was a significant difference in the post-test scores of students' critical thinking skills in the experimental class and the control class. Thus, interactive multimedia based on problem-based learning that has been developed is proven to improve students' critical thinking skills. Therefore, as teachers or educators, they should be able to use various media supported by appropriate learning approaches to improve student learning outcomes, especially to improve 21 st century skills. We recommended future researchers about the development of interactive multimedia with a more varied learning approach to improve 21st century skills on students.

\section{References}

Asta, I. K. R., Agung, A. A. G., \& Widiana, I. W. (2015). Pengaruh Pendekatan Saintifik dan Kemampuan Berpikir Kritis terhadap Hasil Belajar IPA. Mimbar PGSD Undiksha, 3(1), 1-10. http://dx.doi.org/10.23887/jjpgsd.v3i1.5637.

Bijsmans, P., \& Schakel, A. H. (2018). The impact of attendance on first-year study success in problem-based learning. Higher Education, 76(5), 865-881. https://doi.org/10.1007/s10734-018-0243-4.

Borg, W.R. \& Gall, M.D. (1983). Educational research: an introduction (4th edition). Longman. Budiana, I. N., Sudana, D. N., \& Suwatra, I. I. W. (2013). Pengaruh Model Creative Problem Solving (CPS) terhadap Kemampuan Berpikir Kritis Siswa pada Mata Pelajaran IPA Siswa Kelas V SD. Mimbar PGSD Undiksha. http://dx.doi.org/10.23887/jjpgsd.v1i1.816.

Carlgren, T. (2013). Communication, critical thinking, problem solving: a suggested course for all high school students in the 21st century. Interchange, 44, 63-81. https://doi.org/10.1007/s10780-013-9197-8.

Castle, A. (2006). Assessment of the critical thinking skills of student radiographers. Radiography, 12(2), 88-95. https://doi.org/10.1016/j.radi.2005.03.004.

Darsana, I. K. A., Putra, M., \& Negara, I. G. A. O. (2013). Pengaruh penerapan model pembelajaran problem based learning terhadap hasil belajar ipa pada siswa kelas $v$ sd gugus 1 sidemen karangasem. MIMBAR PGSD Undiksha, 1(1). https://dx.doi.org/10.23887/j.jpgsd.v1i1.1482.

Devi, P. S., \& Bayu, G. W. (2020). Berpikir Kritis dan Hasil Belajar IPA Melalui Pembelajaran Problem based learning Berbantuan Media Visual. Mimbar PGSD Undiksha, 8(2), 238-251. http://dx.doi.org/10.23887/jjpgsd.v8i2.26525..

Diputra, K. S. (2016). Pengembangan multimedia pembelajaran tematik integratif untuk siswa kelas iv sekolah dasar. JPI (Jurnal Pendidikan Indonesia), 5(2), 125-133. https://doi.org/10.23887/jpi-undiksha.v5i2.8475.

Effendi, H., \& Hendriyani, Y. (2019). The conceptual and hypothetical model of interactive blended problem based learning. JPI (Jurnal Pendidikan Indonesia), 8(2), 285-292. https://doi.org/10.23887/jpi-undiksha.v8i2.24162.

Filho, W. L. (2018). Encyclopedia of Sustainability in Higher Education. In Encyclopedia of Sustainability in Higher Education. https://doi.org/10.1007/978-3-319-63951-2.

Filipenko, M., \& Naslund, J. A. (2015). Problem-based learning in teacher education. In Problem-Based Learning in Teacher Education. https://doi.org/10.1007/978-3-31902003-7.

Fung, D. C. \& Liang, T.W. (2019). Fostering critical thinking through collaborative group work: insights from hong kong. Springer

Giavrimis, P., Papanis, E., \& Papanis, E.-M. (2011). Information and communication technologies and development of learners' critical thinking: primary school teachers' attitudes. International Education Studies. https://doi.org/10.5539/ies.v4n3p150.

Glenview, I. (1997). Problem based learning and other curriculum models for the multiple intelligences classroom. SkyLight Professional Development

Goertel, R. A. (2018). Critical thinking and reading. The tesol encyclopedia of english language teaching, 1-4. https://doi.org/10.1002/9781118784235.eelt0469. 
Golightly, A., \& Raath, S. (2015). Problem-based learning to foster deep learning in preservice geography teacher education. Journal of Geography, 114(2), 58-68. https://doi.org/10.1080/00221341.2014.894110.

Griffin, P., McGaw, B., \& Care, E. (Eds.). (2012). Assessment and teaching of 21st century skills. Springer Netherlands.

Gunawan, Harjono, A., Herayanti, L., \& Husein, S. (2019). Problem-based learning approach with supported interactive multimedia in physics course: its effects on critical thinking disposition. Journal for the Education of Gifted Young Scientists, 7(4), 1075-1089. http://dx.doi.org/10.17478/jegys.627162.

Ismail, N. S., Harun, J., Zakaria, M. A. Z. M., \& Salleh, S. M. (2018). The effect of mobile problem-based learning application dicscience pbl on students' critical thinking. Thinking Skills and Creativity, 177-195. https://doi.org/10.1016/j.tsc.2018.04.002.

Joham, C., \& Clarke, M. (2012). Teaching critical management skills: The role of problembased learning. Teaching in Higher Education, 17(1), 75-88. https://doi.org/10.1080/13562517.2011.590975.

Lin, Y. (2018). Developing critical thinking in efl classes. In developing critical thinking in efl classes. https://doi.org/10.1007/978-981-10-7784-5.

Liu, M., Liu, S., Pan, Z., Zou, W., \& Li, C. (2018). Examining science learning and attitude by at-risk students after they used a multimedia-enriched problem-based learning environment. Interdisciplinary Journal of Problem-Based Learning, 13(1), 1-11. https://doi.org/10.7771/1541-5015.1752.

Mapeala, R., \& Siew, N. M. (2015). The development and validation of a test of science critical thinking for fifth graders. SpringerPlus, 4(1), 1-13. https://doi.org/10.1186/s40064015-1535-0.

Merritt, J., Lee, M. Y., Rillero, P., \& Kinach, B. M. (2017). Problem-based learning in K-8 mathematics and science education: A literature review. Interdisciplinary Journal of Problem-Based Learning, 11(2), 5-17. https://doi.org/10.7771/1541-5015.1674.

Moallem, M., Hung, W., \& Dabbagh, N. (Eds.). (2019). The wiley handbook of problem-based learning. Hoboken, John Wiley \& Sons, Inc.

Nargundkar, S. (2014). A guided problem-based learning ( pbl ) approach : impact on critical thinking. Decision Sciences Journal of Innovative Education, 12(2), 91-108. https://doi.org/10.1111/dsji.12030.

Ozturk, C., Muslu, G. K., \& Dicle, A. (2008). A comparison of problem-based and traditional education on nursing students' critical thinking dispositions. Nurse Education Today, 28(5), 627-632. https://doi.org/10.1016/j.nedt.2007.10.001.

Sarigoz, O. (2012). Assessment of the high school students' critical thinking skills. Procedia - Social and Behavioral Sciences, 46, 5315-5319. https://doi.org/10.1016/j.sbspro.2012.06.430.

Shinde, V. V., \& Inamdar, S. S. (2013). Problem based learning (PBL) for engineering education in India: Need and recommendations. Wireless Personal Communications, 69(3), 1097-1105. https://doi.org/10.1007/s11277-013-1069-0.

Trilling, B. \& Fadel C. (2009). 21st century skills: learning for life in our times. Jossey-Bass.

Ulger, K. (2018). The effect of problem-based learning on the creative thinking and critical thinking disposition of students in visual arts education. Interdisciplinary Journal of Problem based learning, 12(1), 3-6. https://doi.org/10.7771/1541-5015.1649.

Vieira, R. M., \& Tenreiro-Vieira, C. (2014). Fostering scientific literacy and critical thinking in elementary science education. International Journal of Science and Mathematics Education, 14(4), 659-680. https://doi.org/10.1007/s10763-014-9605-2.

Westwood, P.S. (2008). What teachers need to know about teaching methods. ACER Press.

Widiana, I.W. (2016). Pengembangan asesmen proyek dalam pembelajaran ipa di sekolah dasar. JPI (Jurnal Pendidikan Indonesia), 5(2), 147-157. http://dx.doi.org/10.23887/jpi-undiksha.v5i2.8154. 